Rev. Ter. Ocup. Univ. São Paulo, v. 19, n. 3, p. i, set./dez. 2008.

\title{
Editorial
}

\section{Acessibilidade e visibilidade: nossa revista no Portal de Revistas da USP}

\section{Elisabete Ferreira Mângia', Marta Carvalho de Almeida', Selma Lancman'}

É com grande satisfação e otimismo que partilhamos com pesquisadores, professores, estudantes, profissionais da área e com todos os demais leitores e colaboradores, a entrada da Revista de Terapia Ocupacional na biblioteca eletrônica inaugurada pela Universidade de São Paulo e que dará acesso ao conjunto de periódicos publicados sob responsabilidade da USP.

Em parceria com o Centro Latino-Americano e do Caribe de Informação e Ciências da Saúde - BIREME, o Portal adotou o modelo SciELO de publicação eletrônica.

A importância dessa iniciativa é enorme e, particularmente para nós, proporcionará o acesso irrestrito e a visibilidade, tão esperada e necessária, a área que ainda vive as dificuldades de ser emergente em um contexto de exigências muito elevadas que marcam hoje a possibilidade da pesquisa e das publicações científicas no país.

Esperamos que esse momento e a possibilidade por ele aberta produza o fortalecimento da Revista e faça crescer o interesse em sua consolidação, como uma conquista necessária ao amadurecimento da pesquisa e da produção de conhecimento da Terapia Ocupacional nacional.

Convidamos e convocamos, mais uma vez, aos pesquisadores e estudiosos do amplo campo teórico e prático da Terapia Ocupacional e de suas interfaces a contribuírem com o esforço de ampliar o volume de artigos e a abrangência da Revista para que possamos, um dia, comemorar também sua indexação como um periódico nacional de primeira linha.

Tal conquista é uma meta necessária sem a qual a área ainda vive uma situação de fragilidade em relação ao sistema de pós graduação, que é aquele que hoje no país define o status das áreas que produzem conhecimento.

O caminho da Terapia Ocupacional, que ainda é a menor área da saúde no país em número de profissionais, escolas e pesquisadores, tem sido trilhado com fibra e determinação por muitos que se dedicaram a essa construção nos últimos 30 anos.

O futuro da área depende do nosso trabalho cotidiano, assim confiamos que esse novo espaço-projeto pode ser de todos aqueles que, como nós ,trabalham e acreditam nesse futuro.

O Portal está acessível no endereço http://www.revistasusp.sibi.usp.br/scielo.php

Seja Bem vindo!!

1. Docentes do curso de Terapia Ocupacional do Departamento de Fisioterapia, Fonoaudiologia e Terapia Ocupacional da Faculdade de Medicina da Universidade de São Paulo, editoras da Revista de Terapia Ocupacional da USP. 